Young People, Inequality and Youth Work 
Young People, Inequality and Youth Work is the final book in a series of three dealing with youth issues. The first book, Youth Work, was published in conjunction with the British Association of Social Workers. The second book was Welfare and Youth Work Practice. All three books are edited by Tony Jeffs and Mark Smith. 


\title{
Young People, Inequality and Youth Work
}

\author{
Edited by \\ Tony Jeffs and Mark Smith
}

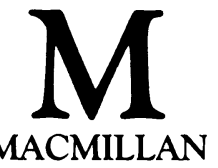


Selection and editorial matter, Chapters 2 and 7 (C) Tony Jeffs and Mark Smith 1990

Individual chapters (C) Don Blackburn, Annie Franklin and Bob Franklin, Peter Kent-Baguley, Keith Popple,

Jean Spence 1990

All rights reserved. No reproduction, copy or transmission of this publication may be made without written permission.

No paragraph of this publication may be reproduced, copied or transmitted save with written permission or in accordance with the provisions of the Copyright Act 1956 (as amended), or under the terms of any licence permitting limited copying issued by the Copyright Licensing Agency, 33-4 Alfred Place, London WC1E 7DP.

Any person who does any unauthorised act in relation to this publication may be liable to criminal prosecution and civil claims for damages.

First published 1990

Published by

MACMILLAN EDUCATION LTD

Houndmills, Basingstoke, Hampshire RG21 2XS

and London

Companies and representatives

throughout the world

Filmset by Wearside Tradespools

Fulwell, Sunderland

British Library Cataloguing in Publication Data

Young people, inequality and youth work.

1. Social work with youth. Great Britain

I. Jeffs, Tony, 1943- II. Smith, Mark, 1950

$362.7^{\prime} 0941$

ISBN 978-0-333-40980-0

ISBN 978-1-349-20405-2 (eBook)

DOI 10.1007/978-1-349-20405-2 


\section{Contents}

List of Tables vi

List of Figures vii

List of Abbreviations viii

Introduction $\quad \mathrm{xi}$

1 Age and Power

Annie Franklin and Bob Franklin 1

2 Demography, Location and Young People Tony Jeffs and Mark Smith

3 Youth Work and Gender Jean Spence

4 Sexuality and Youth Work Practice Peter Kent-Baguley

5 Youth Work and Race Keith Popple

6 Young People, Youth Work and Disability Don Blackburn

7 Young People, Class Inequality and Youth Work Tony Jeffs and Mark Smith

Notes on the Contributors

Bibliography

Name Index

Subject Index 


\section{List of Tables}

7.1 Occupational distribution of people undertaking part-time youth work training in one region ('known' occupations) 


\section{List of Figures}

1.1 Poverty and the life cycle 8

2.1 1983-based population projections, 1983-2001: sex and age-groups (England)

2.2 Regional changes in the number of 16 to 24year-olds in the labour force, 1987-95

7.1 Distribution of the economically active population by occupational category: Great Britain, 1951-81

7.2 Education and labour market status of 16-yearolds, 1975-87

7.3 Ethnicity and the education and labour market status of 16-year-olds, Spring 1986

7.4 Economically active people aged 16 and over, by age, sex and (for women) marital status, and unemployinent rates, Great Britain, Spring 1985

7.5 Average examination attainment by social class in Scotland, 1976, 1980, 1984

7.6 Usage of selected leisure facilities by 14-19year-olds 207

7.7 Youth club attendance - location of provision 211

7.8 Youth club attendance - frequency 212 


\section{List of Abbreviations}

ACE Advisory Centre for Education

ALTARF All London Teachers Against Racism and Fascism

CDP Community Development Project

$\mathrm{CP} \quad$ Community Programme

CRC Community Relations Commission

CRE Commission for Racial Equality

CSO Central Statistical Office

DES Department of Education and Science

DHSS Department of Health and Social Security

FPSC Family Policy Studies Centre

GLC Greater London Council

ILEA Inner London Education Authority

JCGT National Joint Council For Gay Teenagers

L\& GYM Lesbian and Gay Youth Movement

Mencap National Society for Mentally Handicapped

Children

MSC Manpower Services Commission

NACYS National Advisory Council for the Youth

Service

NAME National Anti-Racist Movement in Education

NAYC National Association of Youth Clubs

NYB National Youth Bureau

OPCS Office of Population Censuses and Surveys

PHAB Physically Handicapped and Able Bodied

(Clubs)

PSI Policy Studies Institute

RAT Racism Awareness Training 
TES

UCCA

YMCA

YOP

YTS

YSIC

YWCA
Times Educational Supplement

Universities Central Council on Admissions

Young Men's Christian Association

Youth Opportunities Programme

Youth Training Scheme

Youth Service Information Centre

Young Women's Christian Association 


\section{Introduction}

TONY JEFFS and MARK SMITH

This is the last of three books that have taken as their themes youth work practice, organisation and the social and economic position of young people. In this book we try to avoid revisiting issues and topics dealt with in the other two, concentrating on the social and economic inequalities experienced by young people.

Many of the inequalities that are discussed in this book are reproduced with the help of youth workers and youth organisations. At the same time, with the growth of black political organisation, the re-emergence of the women's movement, the development of lesbian and gay groups, and enhancement of politics around disability, alternative forms of practice have entered the arena. They demonstrate that it is still possible to address questions of inequality and exploitation in day-to-day practice, and that it is still possible to be optimistic about elements of practice, even though successive governments have sought to constrain and marginalise such work. As we have argued elsewhere (Jeffs \& Smith, 1988), the front-line nature of youth work organisation and contradictions in policy-makers' expectations of this area of welfare allow a degree of freedom to practitioners. Even within quite constrained situations, there remains the chance of enabling young people to see something of the forces that influence and restrict their lives. Crucially, there is usually some opportunity, however limited, to work with young people so that they may act upon their understandings. One of our central concerns in this and other books has been to throw some light on the reasons why such chances 


\section{xii Introduction}

have not always been taken, and why certain sites of inequality and oppression, such as those relating to class, still lack sustained critical practice.

The way in which so-called 'progressive' youth work practice has evolved, along specific lines of division, has determined the structure of this book. But approaching the area in this way is fraught with dangers. By examining the discrete, we can easily overlook the interconnections and commonalities. Further, this separation can lead to the trivialising of fundamental ills into 'issues' and, as a consequence, piecemeal responses which add to the process of marginalisation. This is a danger of much so-called 'issuebased' work (see Smith, 1988, pp. 79-81; Jeffs \& Smith, $1989 b)$. Partly for this reason we have brought class division and experience into the centre of the debate, although it has not been represented in a distinctive or major way in practice. This is not to deny in any way that people by virtue of their gender, race, sexuality, age or disabilities suffer major deprivations and discrimination. Capitalism emerged into a situation already stratified, not just by class, but also by these other social divisions. Class relations are shot through with other modes of social differentiation. 'In reproducing capitalism, the state is obliged to reproduce those relationships also' (Coates, 1984, p. 156). Further, the situation is far from static. The very means that are used as the basis of differentiation are also a foundation for powerful collective identities acquired 'by means of their roots in tradition' (Gilroy, 1987, p. 247). Not only are race, gender and other divisions articulated within class, but class relations are also articulated within, say, race. Hence we do not want to enter sterile arguments about what form of division is more important or fundamental. Rather we wish to place the cards on the table in such a way as to open up practice which addresses the causes, rather than the symptoms, of injustice and inequality.

In a similar vein, the function of the book is not to attempt to rework debates regarding the nature of equality and inequality. This is done elsewhere (see, for example, Green, 1981; Giddens \& Held, 1982; Turner 1986; Hindness, 1987). Rather, our aim has been to concentrate on an examination 
of the differences in life chances and experiences encountered by young people in Great Britain. This is largely undertaken in relation to youth work.

At this stage we would like to take the opportunity to thank the contributors. Equally our gratitude needs to be recorded in respect of a number of individuals whose names are absent from the contents page. As always, any enterprise such as this, which consumes so much time and energy, results in the acquisition of debts. Most importantly, we would like to thank friends and families. The order changes but the names remain predominantly the same. To begin, because they complained so much about not coming first in the last dedication, thanks go to Andrew and Alistair Jeffs, in the case of the latter notably for the loan of his library ticket on a number of occasions. To Chris Gibbs who changed her name but not her cheerful tolerance and willingness to offer encouragement. To Christopher Rogers and Alex Rogers for happily operating around us and generously sacrificing both space and time. To Marion Leigh for her comments on the manuscript. Finally to Jackie Apperley who has scant patience with dedications and the like but who, nevertheless, deserves a great deal of thanks. Despite a heavy work-load she found time to act as an unpaid researcher. We will break with an often followed precedent in these matters and avoid gushing thanks to those who might further our careers or lend us money. Instead we will dedicate the book to Sidney G. Hedges, a writer from a different tradition and era, but one who certainly delivered the goods. As avid collectors of his work we would appreciate hearing from others who share this interest or who wish to dispose of duplicates.

TONY JEFFS

MARK SMITH 